\title{
The Strategy in Improving the Income of the Coastal Women toAccelerate Poverty Reductionin South Sulawesi Province
}

\author{
Sri Undai Nurbayani ${ }^{1}$, Nursini ${ }^{2}$, M.Yuzri Zamhuri ${ }^{3}$ \\ \{sri.undai@gmail.com ${ }^{1}$,nini_mahmud@yahoo.com²,mzamhuri@yahoo.com ${ }^{3}$ \} \\ Faculty of Economics and Business, Hasanuddin University, Makassar, Indonesia. ${ }^{1-3}$
}

\begin{abstract}
The long-term goal of this study is to reduce poverty both at the regional and national scale. This study identifies the involvement of Coastal Women in aquaculture and mariculture sectors, as well as the problems faced by Coastal Women in developing the various types of aquaculture and mariculture commodities, and also the support of government programs and policies to women related to the development of fishery commodities. The data used for this research are primary and secondary data, which analyzed through a descriptive statistical analysis model. The research is in the Bone Regency of South Sulawesi Province. The results of this study are useful for local government decision-makers, especially in research sites, to follow the evidence-based Strategy for increasing women's income. Benefits for coastal communities to increase women's labor market participation in the fisheries sub-sector and for improving the income of the fishermen's household.
\end{abstract}

Keywords:

Strategy, Coastal Women, Fishermen, Poverty, fisheries.

Article Received: 18 October 2020, Revised: 3 November 2020, Accepted: 24 December 2020

\section{Introduction}

The maritime and fisheries sector is one of the strategic sector with Coastal areas that are full of potential, but also as an area of high poverty rates. Coastal community livelihood as capture fishermen and marine aquaculture fishers. Production of capture fisheries and aquaculture in South Sulawesi is increasing every year. In 2014, the amount of aquaculture production reached 3.07 million tons. This figure has tripled compared to 2010. Then in 2016, aquaculture production amounted to 3.564 million tons. The number of aquaculture households is 36,618 , and fishing fishermen households are 39,874.

This performance is inseparable from the role of coastal women in each stage of production. Therefore it is interesting to study, what is the role of involvement and contribution to increasing household income? How the accessibility of resources, financial resources in supporting the development of the business units involved, and how the form of the capacity building needed to increase their income. Febriani (2012) explained that women have the potential to carry out various productive activities that generate income and can help the family economy, and more broadly, the national economy. The potential is spread in various fields and sectors. Therefore, to increase the income of women fishermen in coastal areas, it is necessary to have an appropriate and sustainable strategy so that it can accelerate poverty reduction in South Sulawesi Province.

Sofa and Doss (2011), the contribution of the role of women in the agricultural sector is quite large. However, it is impossible to be empirically clarified the amount of contribution made by women. The involvement of women in the labor market varies between countries. However, the trend is generally not paid and as seasonal workers and part-time so that the results are considered less than optimal. Costa, Silva, and Vaz (2009) find that increasing women's access to the labor market can reduce poverty and income inequality in Latin America. Several empirical studies have found that women's involvement in various economic activities contributes to increasing family income (Hendayana and Wahyuni, 2001). 
The agricultural sector and fisheries sub-sector are engines of growth and poverty reduction. The importance of the role of women in business or economy, Khanifah (2012), that as many as 6 million households in Indonesia are headed by women and every year the head of a woman's family increases by $14 \%$ which has the potential to improve the family economy if it can carry out a variety of family economic business activities with there is support through involvement in making apostasy and providing opportunities to attend formal and non-formal education. Hidayah et al. (2010), that the participation of women in the family's socioeconomic life was proven to be able to improve the family economy, agricultural production, non-agricultural business production, and community welfare, with supporting factors, among others; economic conditions of women who are in the middle to lower level, social activities that are followed, cooperation between workers in the agricultural and non-agricultural sectors and inhibiting factors, among others; weak physical condition, double workload, access and control in the household. Meanwhile, according to Forddanta (2012), women's education, time allocation, and work experience of women will affect women's income. The importance of a strategy to increase household income is supported by De Janvry, Alain and Sadoulet, Elisabeth, (2001) for Mexico and Barrett, Christopher B; Reardon, Thomas; Webb, Patrick, (2001) in Rural Africa.

\section{Research Methodology}

This research uses descriptive and explanatory research approaches. The unit of analysis in this study is the aquaculture household and the capture fisheries household. 40 respondents at Tanete Riattang Timur Subdistric, 20 respondents at Panyula Village and 20 respondents, the aquaculture household at Toro village.

The research location is in the Province of South Sulawesi, Bone Regency. The reason for choosing the location is based on considerations: (i) is a production center for aquaculture such as seaweed. (ii) the number of marine fisheries and aquaculture households is relatively large compared to other districts, (iii) the district has a fish landing area (TPI)

\section{Result and Discussion}

Based on the results of research, the study discusses the role and contribution of coastal women in the production process, problems and challenges faced assistance or support from the government as well as institutional strengthening needed by coastal women.

\subsection{Involvement and Contribution of Women Seaweed Farmers and Capture Fishermen}

The involvement of coastal women, in the seaweed cultivation production process, is carried out at the stage before the grower and after harvest. The work before planting takes the form of tying the seeds to a rope; one hundred percent is done by women. Conversely, at the time of planting, carried out by men. Activities after harvesting in the form of drying or drying seaweed, everything is done by women, likewise in processing seaweed into cakes and crackers. The role of women in this activity can contribute to an increase in household income by $40-60$ percent.

In the capture fishermen group, when the husband goes to sea, their wives spend time working as laborers on the production of fish fogging. They can increase household income by 30-40 percent. This wage is beneficial for the family's economy, and it can be used to use it for daily household needs and the benefit of children's schooling.

This study is in line with Fachry (2009) that women or fishermen's wives participate in the process of seaweed cultivation in the form of decision making in financial aspects, binding the seeds and post-harvest. They are more involved in land-based work such as making rope, binding the seeds, and drying seaweed.

The low income of fishers encourages the role of women/wives of fishers as part of sustaining the family economy, through their involvement in making additional income. Because of this, the 
contribution of the fishermen's wife's workforce has increased significantly. The fisherman's wife, besides having a role in household affairs, also plays an essential economic function in the household.

\subsection{Problems and Challenges Faced by}

\section{Seaweed Aquaculture Fishermen and} Capture Fishermen

Various obstacles and problems faced by fishermen (farmers) seaweed cultivation. Barriers at the production stage, Most seaweed farmers, face the problem of lack of capital, lack of labor (because almost every household cultivates seaweed) so that they have to take turns helping from house to house to tie seaweed seeds. Weather factors also become an obstacle; for example, in the rainy season, seaweed can not grow well, high waves, also inhibit the growth of seaweed. Another obstacle is the presence of disease, as well as the attachment of marine biota, a type of small shells to seaweed.

The obstacle after harvest is the weather for example, the rainy season. When continuous rain causes no sunlight, seaweed cannot dry. There is no particular place / permanent floor that is used as a drying place for drying seaweed. Farmers do the drying only in the yard or on the shoulder of the road. Constraints in marketing, they cannot do marketing. They do not have transportation, so they wait for the traders who come to collect the harvest. For the production of processed seaweed, they have made brownies from seaweed, crackers. This business is managed in groups; the obstacle they face is that the production business is not sustainable due to marketing that is not fixed. For the production of crackers, the constraints are that the packaging is not functional or attractive.

For smoked fish production, the constraints faced are highly dependent on the availability of raw materials in the form of large tuna fish or skipjack fish. During the rainy season, large tuna/skipjack fish are reduced. Firewood is also challenging to obtain.
Barriers to fishing households are lack of equipment, boats/fishing gear. The next obstacle is the number of operational costs when going to sea to catch marketing. For example, having to pay fees for places to sell at the market, pay for motorbikes when parking. Must also pay tribute when crossing certain areas (Kalitua village) they must pay, sometimes with fish or diesel. Another obstacle is the absence of a conveyance to market the catch.

\subsection{Support government programs for women Seaweed Farmers and Capture Fishermen}

Government assistance in the form of processed seaweed training, how to make seaweed brownies and seaweed crackers, and milkfish thorn training. While the assistance of facilities in the form of nylon ropes for seaweed stretches. Assistance for fishers in the form of training from the Fisheries Service. Aid facilities such as fish baskets, fish basins, fish cork boxes, smoked equipment, freezers, and press equipment. They have also received training in Makassar, and received funds to build a fumigation house,

\subsection{The form of capacity strengthening needed by women fishermen in seaweed cultivation and Capture Fishermen}

Strengthening the capacity needed by women who cultivate seaweed and capture fishers is support from the regional government in the form of programs that can provide additional capital as well as training programs and equipment rocks.

Meanwhile, community institutions can take the form of capital assistance and assistance. Educational institutions can play a role in mentoring in the form of improving skills and marketing pioneering and improving business management. There is still a need to strengthen cooperation between groups when conducting daily production activities.

To improve the welfare of coastal households, the following models can be adopted, Figure 1. Model of 1 of the Strategy in improving the income of the coastal women 


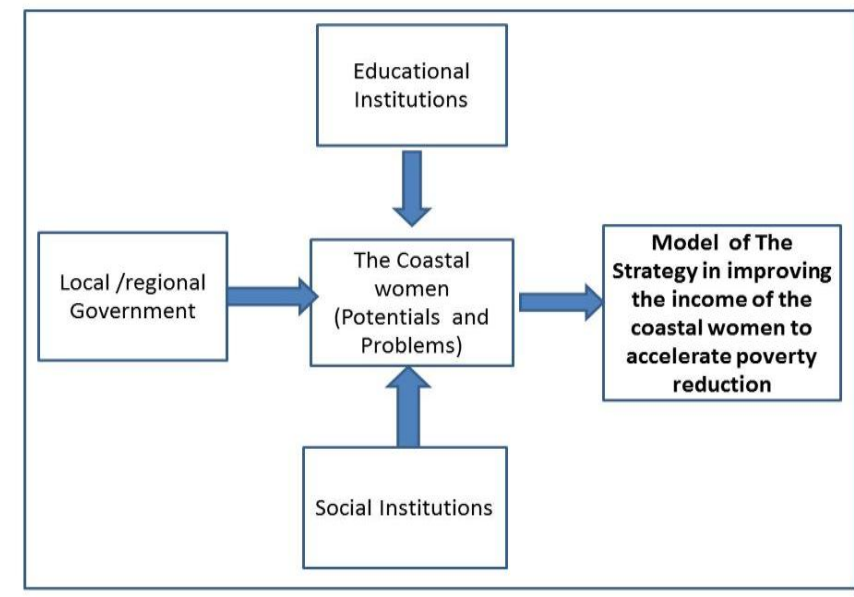

Fig. 1. Model of 1 of the Strategy in improving the income of the coastal women.

\section{Conclusion}

Involvement of women fishermen and their contribution to increasing family income in the seaweed aquaculture sub-sector is to play a role in the process of tying and drying seaweed, as well as making processed seaweed. In capture fisheries, fishers women have the role of processing fishermen's catches into smoked fish and selling them in the market. The income earned significantly helps the economics of fishing households. Increase household income by 30 to 60 percent. The main problems faced are lack of capital, lack of equipment, and problems in marketing. Therefore local government assistance in the form of additional equipment, additional capital, and training is still very much needed. To strengthen capacity, collaboration and group strengthening must be carried out with direction/assistance from the local government, educational institutions, and local community social institutions.

\section{Acknowledgments.}

Thanks to chairman melati group at Panyula village and Toro village

\section{References}

[1] Barrett, Christopher B. Reardon, Thomas, Patrick, 2001. Nonfarm Income Diversification and Household Livelihood Strategies in Rural Africa: Concepts,
Dynamics and Policy Implications (August, 2001). Food Policy, Vol. 26, No. 4, Available at SSRN: https://ssrn.com/abstract=1847711

[2] Costa, J; Silva,E; Vaz,Fabio; 2009. The Role of Gender Inequalities in Explaining Income Growth, Poverty and Inequality: Evidence From Latin American Countries. Working Paper No.52. April

[3] De Janvry, Alain dan Sadoulet, Elisabeth, 2001. Income Strategies Among Rural Households in Mexico: The Role of Off-farm Activities. Artikel in World Bank. blication at:

https://www.researchgate.net/publication/475 6083.

[4] Fachry, Mardiana, E,. 2009. Analysis of the Family Profile of Seaweed Cultivators Viewed from the Aspect of Gender Roles in Jeneponto Regency. Proceding. Konas Ambon.

[5] Forddanta Dityasa Hann, 2012The role of women in supporting the economy of poor families is measured in terms of income. Case Study in Kendal Dendal. Skripsi, Fakultas Ekonomi, Universitas Diponegoro, Semarang.

[6] Febriani, 2012. The Role of Women in the Development of Small and Medium Enterprises in the City of Padang. Journal of Management and Ent, Volume 3 No.3, ISSN: 2086-5031. Padang

[7] Hendayana dan Wahyuni, (2001). Dimensi Peran Gender dalam pengembangan usaha ternak rakyat di Kawasan Timur Indonesia. Med.Pet.Vol 24 No.1 pp:27-32

[8] Hidayah, Rana. 2010. Peran Perempuan dalam Rumah Tangga Nelayan. Prosiding Seminar Kedaulatan pangan dan Energi.

[9] Khanifah (2012). Analisis Pergeseran Struktur Perekonomian Dan Penentuan Sektor Unggulan Atas Dasar Penyerapan Tenaga Kerja Di Kabupaten Magelang. Prosiding seminar Ekonomi.

[10] Sofa Team and Doss, Cheryl (2011). The Role of Women in Agriculture. ESA Working paper No.11-02 March. Agricultural Development Economic Devision FAO. 